\title{
Ceramic Workers and the Inflammatory Effects of the Silica Dust on the Nasal Mucosa Detected by Nasal Cytology: a Pilot Study
}

Elona Begvarfaj ( $\sim$ ebegvarfaj@yahoo.it )

ENT Istituto Neurotraumatologico Italiano

\section{Emilio Greco}

Link Campus University

Arturo Armone Caruso

AIAS

Simonetta Masieri

Sapienza University

\section{Carmelita Velardita}

Unità Locale Socio Sanitaria (ULSS) 2

\section{Carlo Cavaliere}

Sapienza University

\section{Research Article}

Keywords: nasal cytology, ceramic workers, silicosis, upper airways, inflammation, occupational rhinitis, occupational health, quality of life, social health

Posted Date: January 21st, 2022

DOI: https://doi.org/10.21203/rs.3.rs-1250460/v1

License: (c) (i) This work is licensed under a Creative Commons Attribution 4.0 International License. Read Full License 


\section{Abstract}

Background. Adverse health effects due to occupational exposures are a global public health concern and have been studied for many years. Ceramic workers are occupationally exposed to a wide range of toxic substances as they manage clay (silico-aluminous feldspar mixed with sodium, potassium salts and iron oxide). The objective of this study was to assess the presence of any inflammation or alteration of the nasal mucosa of ceramic workers by nasal cytology.

Materials and methods. Ceramic workers from Caltagirone (Italy) were enrolled. Nasal symptoms, atopy, health habits and workplace features were assessed by a special questionnaire, and nasal mucosa health was evaluated by nasal cytology.

Results. The cytological study of the nasal mucosa showed the constant presence of abundant, thick and filamentous mucus, as well as a reorganization of the nasal cellularity with a prevalence of muciparous metaplasia and almost total absence of hair cells, for almost all of the subjects.

Conclusions. A significant proportion of ceramic workers showed chronic inflammatory rhinitis on nasal cytology, with a remodelling of the nasal mucosa and thick mucus. Nasal cytology may be a helpful tool for the screening of any pathology of the upper airways.

\section{Background}

Adverse health effects due to occupational exposures are a global public health concern and have been studied for many years. A high incidence of silicosis and other pulmonary diseases in the ceramic working population has been reported from Japanese researchers in the early decades of the last century $[1,2]$. It is well documented that workers engaged in pottery-related industries are at great risk for pulmonary diseases, lead and other metal poisoning, as well as other toxic reactions caused by occupational exposure to clays, glazes, and furnace emissions [3]. Some reports indicate that 1,7 million workers in the United States [4] and over 3 million workers in Europe [5] are exposed to crystalline silica.

Silicosis is a well-known consequence of exposure to silica dust, and long-term exposure to crystalline silica has also been associated with the risk of developing lung cancer, pulmonary tuberculosis, and other airway diseases [6-8]. On the other hand, glaze or crystallinity, enamel and colours randomly used for decorations, may play a direct irritating action on airway epithelial cells. Since 1997, crystalline silica has been classified as a human carcinogen by the International Agency for Research on Cancer (IARC) [9], and a worldwide series of risk assessments has been conducted for respirable silica dust exposure, especially for low levels of exposure [10-13]. Although advances in occupational safety make this disorder quite avoidable, silicosis remains the most prevalent occupational disease in both developed and developing countries [14].

Health surveillance is provided to workers regularly exposed to respirable silica exclusively for lung diseases. In practice, the assessment for workers at high risk for occupational exposures, would include 
any respiratory questionnaire, lung function testing and a baseline chest $X$-ray for comparison with future chest X-rays [15-17]. However, there is evidence that chronic inflammatory changes in the upper airways may precede the development of lung injuries even in the absence of radiological signs or symptoms [18, 19], and early screening of any changes in the normal functioning of the mucosa of the upper airways may be beneficial for the implementation of adequate preventive measures and amelioration of worker health and quality of life.

The aim of our study was to assess whether silica exposure correlated with specific inflammatory patterns of the nasal mucosa, and nasal cytology was used as a diagnostic tool for sampling of the nasal mucosa.

\section{Materials And Methods}

Ceramic workers from the city of Caltagirone were invited to participate in the study. Caltagirone is an Italian center, that is well-renowned for its long handcrafted-ceramic tradition. Forty-five ceramic workers volunteered, and 28 of them were selected to participate in the study according to the inclusion and exclusion criteria. The inclusion criteria were: a) workers from the hand-crafted ceramic sector; and b) workers with a minimal duration of employment of 1 year. The exclusion criteria were: a) pregnancy and lactation; b) presence of any malignancy and diseases of the immune system; c) acute and subacute infections of the airways, chronic lung diseases, chronic rhinosinusitis with or without nasal polyposis; and d) therapies affecting the health of nasal mucosa (nasal sprays with corticosteroids and/or antihistamines, oral antihistamines, NSAIDs). The study was approved by the ethical committee of AIAS di Afragola, and written consent was obtained from all the participants.

The participants were administered a self-report questionnaire to investigate the presence of nasal symptoms (nasal obstruction, rinorrhea, itching and sneezing), presence of atopy and previous nasal interventions, cigarette smoking history, climate of the areas of residence and work, and workplace habits (years of exposure, type of clay and techniques of clay processing, use of plaster molding, methods of drying and firing the pieces, use of glaze, enamels or colours and techniques of decoration).

Nasal cytology: Written informed consent was obtained from any subject. Cytologic sampling was carried out by a scraping technique, i.e., by crawling a cytology plastic curette (IR Medical, Lugo, Italy), 2-3 times on the mucous surface of the central area of the inferior turbinate. The nasal mucosal cells were placed on an electrostatically charged cytology slide (Superfrost Plus Menzel-Gläser, Thermo Scientific, Milan, Italy). The cells were then stained according to the panoptic method ( $3 \mathrm{~min}$ in pure May-Grunwald dye (Carlo Erba, Milan, Italy), 6 min in 50\% May-Grunwald dye, 1 min in bidistilled water (Carlo Erba, Milan, Italy) and $30 \mathrm{~min}$ in Giemsa solution (Carlo Erba, Milan, Italy) diluted 1:10 v/v). The slide was then covered with a glass cover of $24 \times 50 \mathrm{~mm}$ and observed under an optical microscope (Nikon Eclipse 50i) at $1000 \times$ oil-immersion enlargement, over fifty observational fields. The images were recorded using a Nikon DS1 camera and digitized using a NIS-D elements computer support Eventually the samples were observed at microscope by the same investigator who assessed according to a $0-4$ score $(0=$ none, $1=$ 
rare, $2=$ some, $3=$ easily visible and $4=$ many) the presence and number of goblet cells, neutrophils, eosinophils, mast cells, bacteria and fungi [20].

The study was conducted in accordance with the International Conference on Harmonisation Good Clinical Practice, the Declaration of Helsinki and all applicable laws and regulations.

\section{Statistical analysis}

Values are reported as a median (range) or a number (percentage), except where explicitly stated. A value of $p<0.05$ was considered to be statistically significant. The entire analysis was performed Statistica 12 software (Statsof).

\section{Results}

Twenty-eight ceramic workers aged between 19 and 64 years old (mean age 46,28 years old) participated in the study. All of them resided in the town of Caltagirone characterized by a humid climate. The overall duration of the ceramic working period was 27,82 years. The working setting consisted of minor industries located in homes or small factories.

Of the 28 subjects, 8 (28,57\%) were allergic ( 3 to grasses, 1 to mites, 2 to parietaria, 1 to alternaria, 1 to grass and mites), 3 (10,71\%) had previous upper airway surgery (2 adenoidectomy, 1 septoplasty), 9 $(32,14 \%)$ were smokers and $5(17,85 \%)$ were former smokers. Nasal symptoms were reported by all the participants. Nasal congestion was the main symptom, followed by sneezing and itching of the nasal mucosa. In particular, the subjects who reported sneezing referred it as immediately as they entered their workplaces or during contact with the glazes and crystalline materials.

All of them worked the refined clay by hand. $89,28 \%$ of the study population ( 25 subjects) reported that either the process of clay modelling, or its drying and firing, took place in the same environment, while 3 of them $(10,71 \%)$ made use of an electric oven for the firing process, placed in a separate room from the workroom.

Room air extractors were present only in 5 cases (17,85\%): located inside of the laboratory for 2 subjects, and for the other 3 , the air extractors were placed where the electric oven was situated. Only 6 participants $(21,42 \%)$ did not make use of plaster molding.

For the decoration techniques, 18 subjects $(64,28 \%)$ used hand painting, while the other $10(35,71 \%)$ made use of spray decoration. Two subjects $(7,14 \%)$ made exclusive use of watery colours; otherwise, the others $26(92,85 \%)$ used crystalline metal oxides, and enamels.

The cytological study of the nasal mucosa revealed the constant presence of abundant, thick and filamentous mucus, generally tending to be basic (Fig. 1). The mucus was detected in a lower quantity only in the samples of three subjects $(10,7 \%)$, the ones with the oven in a separate room. In 10 participants (35,71\%), precipitates and dust were documented (Fig. 2,3). 
From a strictly cytological point of view, there was a reorganization of the nasal mucosa structure with a prevalence of muciparous metaplasia (Fig. 4) and numerous polynucleations (Fig. 3) and an almost total absence of hair cells; for rather all the subjects, 26 out of 28 or $92,85 \%$.

Regarding the presence of inflammatory cells, 10 participants $(35,71 \%)$ presented a majority of neutrophilic granulocytes (Fig. 1). Of the 8 allergic patients, nasal samples from 5 of them showed very rare neutrophils, and many lymphocytes and eosinophils were found only in a single rhinocytogram.

\section{Discussion}

The principal components of ceramic and enamel mixtures consist of crystalline silica particles (an average of $35 \%-38 \%$ for vitreous China and $22 \%-26 \%$ enamel) and other minerals such as $\mathrm{Al}$, Fe, and FeCrNi alloys [21]. Occupational exposure to silica dust is well-known to be related to a higher risk of many malignant and other respiratory diseases [18, 22, 23].

The development of occupational diseases is highly conditioned by work environment characteristics [24] and the application of prevention measures, as predicted by the current legislation $[25,26]$. Studies have indicated that workers of small ceramic factories present a poorer health-related quality of life and a higher incidence of silicosis-related airway diseases, due to poor environmental conditions, irregular working hours and a high proportion of older employees [27, 28]. Our data were consistent with these studies, as the majority of the participants reported that the different ceramic working processes took place in the same environment lacking protective measures: only $10,71 \%$ of our subjects made use of an electric oven placed in a separate area from the workroom, and 17,85\% used an aspiration system. The only participants with a smaller quantity of mucus and inflammatory cells were those (3 out of 28) who made exclusive use of tempera colours and had a separate area provided with aspiration systems for the firing phase. Furthermore, the age of the majority of our subjects was over 60 years old.

The primary aim of this study was to assess whether silica exposure correlated with specific inflammatory patterns of the nasal mucosa. In our sample, quite all of the subjects reported nasal congestion with itching and sneezing. It is difficult to assess whether these data are in accordance with the results of other studies. There is a lack of data about the epidemiology of nasal symptoms due to the occupational exposure of ceramic workers, as the majority of studies have focused on lower airway silica-related diseases.

The nasal mucosa is the first target that comes into contact with airborne pollutants and the initial site of injury induced by them [29]. The mucous layer on its surface has an important function in relation to the conditioning of inhaled air and provides an adhesive surface for the deposition of inhaled particles [30]. Studies have demonstrated the potential value of nasal epithelial cells for the prediction of lung cancer risk [31]. As widely demonstrated, nasal epithelial cells, sampled either by brushing or scraping, allow the detection of toxic and inflammatory effects of airborne pollutants such as tobacco smoking, environmental carcinogens and silica [32-34]. To rule out the influence of any pollen on the nasal 
mucosa, nasal cytology took place in November, in accordance with the data of the pollinic calendar of the area.

On nasal cytology, our ceramic workers presented a rearrangement of the respiratory epithelium of the nasal mucosa, a total absence of ciliated cells and a significant increase in the goblet (mucous) cell number. This pattern is described as mucous metaplasia [30]. Remodelling of the nasal mucosa has important consequences, as the diminution of ciliated cells and the increase in goblet cells cause hypersecretion of mucus and its subsequent sinonasal stagnation [29, 30, 32]. Reduced mucociliary transport is a major factor in the pathogenesis of rhinitis, sinusitis and other airway pathologies [35]. The presence of dust precipitates and inflammatory cells such as neutrophils and lymphocytes, is consistent with a picture of chronic inflammatory rhinitis [29]. We suggest that silica dust may act as a mucous membrane irritant, activating an inflammatory response. Since the turnover of ciliated cells is approximately 21 days, persistent inflammation may prevent the recovery of the nasal mucosa to a healthy epithelium. As a consequence of nasal obstruction, rinorrhea or sneezing occur with an important impact on worker quality of life [36].

A strong limitation of the current study is the limited sample size and the absence of a control group. A further limitation of the study was the lack of exposure data; thus, it was not possible to perform any correlation of it with the inflammatory pattern presented in the nasal mucosa.

A strength of our study is that the presence of any inflammatory pattern was analysed in the mucosa of the upper airways, rather than in peripheral blood cells or in the bronchial mucosa. In fact, the nasal mucosa is a target tissue of airborne pollutants, and its sampling can be achieved by minimally invasive methods, e.g., nasal scraping. The principal advantages of nasal scraping consist of being economical, noninvasive and easy to perform in an outpatient situation (we performed nasal scraping at the workplaces of the participants, and the smears were easier to handle than other kinds of samplings). Other studies have confirmed the reliability of nasal cytology as a screening tool for chronic inflammatory rhinitis [32, 34].

In conclusion, a significant proportion of ceramic workers showed a chronic inflammatory rhinitis on nasal cytology, with a remodelling of the nasal mucosa and thick mucus. Nasal cytology is a very helpful tool for the screening of early pathologic changes of the nasal mucosa to implement adequate protective measures and therapies aiming to improve worker health and quality of life. Further investigations in larger populations are required to assess the relation of the exposure levels of silica and the use of prevention equipment to the inflammatory patterns of rhinitis.

\section{Declarations}

\section{Disclosure And Financial Support:}

All the authors do not have conflicts of interest. This study did not receive any financial support. 


\section{Authorship:}

Elona Begvarfaj: Writing - Review \& Editing, Writing - Original Draft,

Emilio Greco: Review \& Editing, Supervision

Arturo Armone Caruso: Conceptualization, Writing - Original Draft

Simonetta Masieri: Review \& Editing, Supervision

Carmelita Velardita: Nasal cytology sampling

Carlo Cavaliere: Review \& Editing, Supervision

\section{Data availability statement}

The data that support the findings of this study are available from the corresponding author upon reasonable request.

\section{References}

1. Fuortes LJ. Health hazards of working with ceramics. Postgrad Med 1989;85:133-6.

2. Matsushima $\mathrm{T}$, Ubuno $\mathrm{T}$, Ito $\mathrm{H}$, et al. Silicosis and silicotuberculosis among pottery workers. Japanese Journal of Industrial Health 1965;7:507-1 1. (In Japanese with English abstract.)

3. Hasegawa S. Studies on the silicosis in Seto ceramics plants in Aichi prefecture, comparison of their roentogenological classification with results by pulmonary function tests. Japanese Journal ofIndustrial Health 1963;5:45-59. (In Japanese with English abstract.)

4. Chen W, Liu Y, Wang H, Hnizdo E, Sun Y, et al. (2012) Long-Term Exposure to Silica Dust and Risk of Total and Cause-Specific Mortality in Chinese Workers: A Cohort Study. PLoS Med 9(4): e1001206. doi:10.1371/journal.pmed.1001206

5. Brown TP, Rushton L (2005) Mortality in the UK industrial silica sand industry: first assessment of exposure to respirable crystalline silica. Occup Environ Med 62:442-445.

6. Steenland K (2005) One agent, many diseases: exposure-response data and comparative risks of different outcomes following silica exposure. Am J Ind Med 48: 16-23.

7. US National Institute for Occupational Safety and Health (2002) Health effects of occupational exposure to respirable crystalline silica. Washington District of Columbia): US Department of Health and Human Services.

8. Kauppinen T, Toikkanen J, Pedersen D, Young R, Kogevinas M, et al. (1998) Occupational exposure to carcinogens in the European Union in 1990-93. Carex: International Information System on Occupational Exposure to Carcinogens. Helsinki: Finnish Institute of Occupational Health. 
9. Silica, Some Silicates, Coal Dust, and Para-Aramid Fibrils. In IARC Monographs on the Evaluation of Carcinogenic Risks to Humans; WHO: Lyon, UK, 1997; Volume 68.

10. Steenland, K.; Mannetje, A.; Boffetta, P.; Stayner, L.; Attfield, M.; Chen, J.; Dosemeci, M.; DeKlerk, N.; Hnizdo, E.; Koskela, R.; et al. International agency for research on cancer. Pooled exposure-response analyses and risk assessment for lung cancer in 10 cohorts of silica-exposed workers: An IARC multicentre study. Cancer Causes Control 2001, 12, 773-784.

11. Mannetje, A.; Steenland, K.; Attfield, M.; Boffetta, P.; Checkoway, H.; DeKlerk, N.; Koskela, R.S. Exposure-response analysis and risk assessment for silica and silicosis mortality in a pooled analysis of six cohorts. Occup. Environ. Med. 2002, 59, 723-728.

12. Attfield, M.; Costello, J. Quantitative exposure-response for silica dust and lung cancer in Vermont granite workers. Am. J. Ind. Med. 2004, 45, 129-138.

13. Chen, W.; Zhuang, Z.; Attfield, M.; Chen, B.T.; Gao, P.; Harrison, J.C.; Fu, C.; Chen, J.Q.; Wallace, W.E. Exposure to silica and silicosis among tin miners in China: Exposure-response analyses and risk assessment. Occup. Environ. Med. 2001, 58, 31-37.

14. Information Note of International Labour Office (ILO). In Proceedings of Thirteenth Session of the Joint ILO/WHO Committee on Occupational Health, Geneva, Switzerland, 9-12 December 2003.

15. Dement JM, Welch L, Bingham E, et al. Surveillance of respiratory diseases among construction and trade workers at Department of Energy nuclear sites. Am J Ind Med 2003;43:559-73.

16. Welch LS, et al. Occup Environ Med 2019;76:137-142. doi:10.1136/oemed-2018-105431.

17. Health surveillance for those exposed to respirable crystalline silica (RCS). Supplementary guidance for occupational health professionals (amended January 2016). .

18. Hnizdo E, Vallyathan V. Chronic obstructive pulmonary disease due to occupational exposure to silica dust: a review of epidemiological and pathological evidence. Occup Environ Med. 2003 Apr;60(4):237-43. doi: 10.1136/oem.60.4.237.

19. Moscato G, Pala G, Perfetti L, Frascaroli M, Pignatti P. Clinical and inflammatory features of occupational asthma caused by persulphate salts in comparison with asthma associated with occupational rhinitis. Allergy. 2010; 65:784-790.

20. Cantone E, Cavaliere M, Begvarfaj E, Motta S, lengo M. New therapeutic strategies for the treatment of recurrent respiratory tract infections in children. J Biol Regul Homeost Agents. 2020;34(3):11851191.

21. Falchi M, Paoletti L, Mariotta s, Giosue s, Guidi L, Biondo L, Scavalli P, Bisetti A. Non-fibrous inorganic particles in bronchoalveolar lavage fluid of pottery workers. Occup Environ Med 1996;53:762-766.

22. Ehrlich R, Akugizibwe P, Siegfried N, Rees D. The association between silica exposure, silicosis and tuberculosis: a systematic review and meta-analysis. BMC Public Health (2021) 21:953 https://doi.org/10.1186/s12889-021-10711-1.

23. Yarahmadi A, Zahmatkesh MM, Ghaffari M, Mohammadi S, Labbafinejad Y, Seyedmehdi SM, Nojomi $\mathrm{M}$, Attarchi M. Correlation between silica exposure and risk of tuberculosis in Lorestan Province of Iran. Tanaffos. 2013;12(2):34-40. 
24. Identification and control of work-related diseases: report of a WHO expert committee. 1985., World Health Organization; Albany, NY : WHO Publications Centre USA

25. Cirla A.M. "Effetti di ipersensibilità nelle attività di verniciatura". Atti "Attività di verniciatura: salute e sicurezza". Ed. Cimal - Milano (2009) 54-68.

26. Regulation (EC) No 1272/2008 of the European Parliament and of the Council of 16 December 2008 on classification, labelling and packaging of substances and mixtures, amending and repealing Directives 67/548/EEC and 1999/45/EC, and amending Regulation (EC) No 1907/2006 (Text with EEA relevance). OJ L 353, 31.12.2008, p. 1-1355. http://data.europa.eu/eli/reg/2008/1272/oj.

27. Huang J, Shibata E, Takeuchi Y, Okutani H. Comprehensive health evaluation of workers in the ceramics industry. British Journal of Industrial Medicine1993;50:112-116.

28. Fielding JE, Piserchia PV. Frequency of worksite health promotion activities. Am J Public Health. 1989 Jan;79(1):16-20. doi: 10.2105/ajph.79.1.16.

29. Wise SK, Lin SY, Toskala E, Orlandi RR, Akdis CA, Alt JA, Azar A, Baroody FM, Bachert C, Canonica GW, Chacko T, Cingi C, Ciprandi G, Corey J, Cox LS, Creticos PS, Custovic A, Damask C, DeConde A, DelGaudio JM, Ebert CS, Eloy JA, Flanagan CE, Fokkens WJ, Franzese C, Gosepath J, Halderman A, Hamilton RG, Hoffman HJ, Hohlfeld JM, Houser SM, Hwang PH, Incorvaia C, Jarvis D, Khalid AN, Kilpeläinen M, Kingdom TT, Krouse H, Larenas-Linnemann D, Laury AM, Lee SE, Levy JM, Luong AU, Marple BF, McCoul ED, McMains KC, Melén E, Mims JW, Moscato G, Mullol J, Nelson HS, Patadia M, Pawankar R, Pfaar O, Platt MP, Reisacher W, Rondón C, Rudmik L, Ryan M, Sastre J, Schlosser RJ, Settipane RA, Sharma HP, Sheikh A, Smith TL, Tantilipikorn P, Tversky JR, Veling MC, Wang Y, Westman M, Wickman M, Zacharek M. International Consensus Statement on Allergy and Rhinology: Allergic Rhinitis. Int Forum Allergy Rhinol. 2018 Feb;8(2):108-352. doi: 10.1002/alr.22073. PMID: 29438602.

30. Heffler E, Landi M, Caruso C, Fichera S, Gani F, Guida G, Liuzzo MT, Pistorio MP, Pizzimenti S, Riccio AM, Seccia V, Ferrando M, Malvezzi L, Passalacqua G, Gelardi M. Nasal cytology: Methodology with application to clinical practice and research. Clin Exp Allergy 2018;48:1092-1106.

31. McDougall CM, Blaylock MG, Douglas JG, Brooker RJ, Helms PJ, Walsh GM. Nasal epithelial cells as surrogates for bronchial epithelial cells in airway inflammation studies. Am J Respir Cell Mol Biol. 2008;39(5):560-8. doi: 10.1165/rcmb.2007-03250C.

32. Peluso ME, Munnia A, Giese RW, Chellini E, Ceppi M, Capacci F. Oxidatively damaged DNA in the nasal epithelium of workers occupationally exposed to silica dust in Tuscany region, Italy. Mutagenesis. 2015 Jul;30(4):519-25. doi: 10.1093/mutage/gev014.

33. Peluso M. E. M. Munnia A. (2014) DNA adducts and the total sum of at-risk DNA repair alleles in the nasal epithelium, a target tissue of tobacco smoking-associated carcinogenesi. Toxicol. Res., 3, 4249.

34. Lovato A, Staffieri C, Ottaviano G, Cappellesso R, Giacomelli L, Bartolucci GB, Scapellato ML, Marioni G. Woodworkers and the inflammatory effects of softwood/hardwood dust: evidence from nasal cytology. Eur Arch Otorhinolaryngol 2016; 273:3195-3200. 
35. Bachert C, Marple B, Schlosser RJ, Hopkins C, Schleimer RP, Lambrecht BN, Bröker BM, Laidlaw T, Song WJ. Adult chronic rhinosinusitis. Nat Rev Dis Primers. 2020 Oct 29;6(1):86. doi: 10.1038/s41572-020-00218-1.

36. Vandenplas O, Suarthana E, Rifflart C, Lemière C, Le Moual N, Bousquet J. The Impact of WorkRelated Rhinitis on Quality of Life and Work Productivity: A General Workforce-Based Survey. J Allergy Clin Immunol Pract. 2020;8(5):1583-1591.e5. doi: 10.1016/j.jaip.2019.12.033.

\section{Figures}

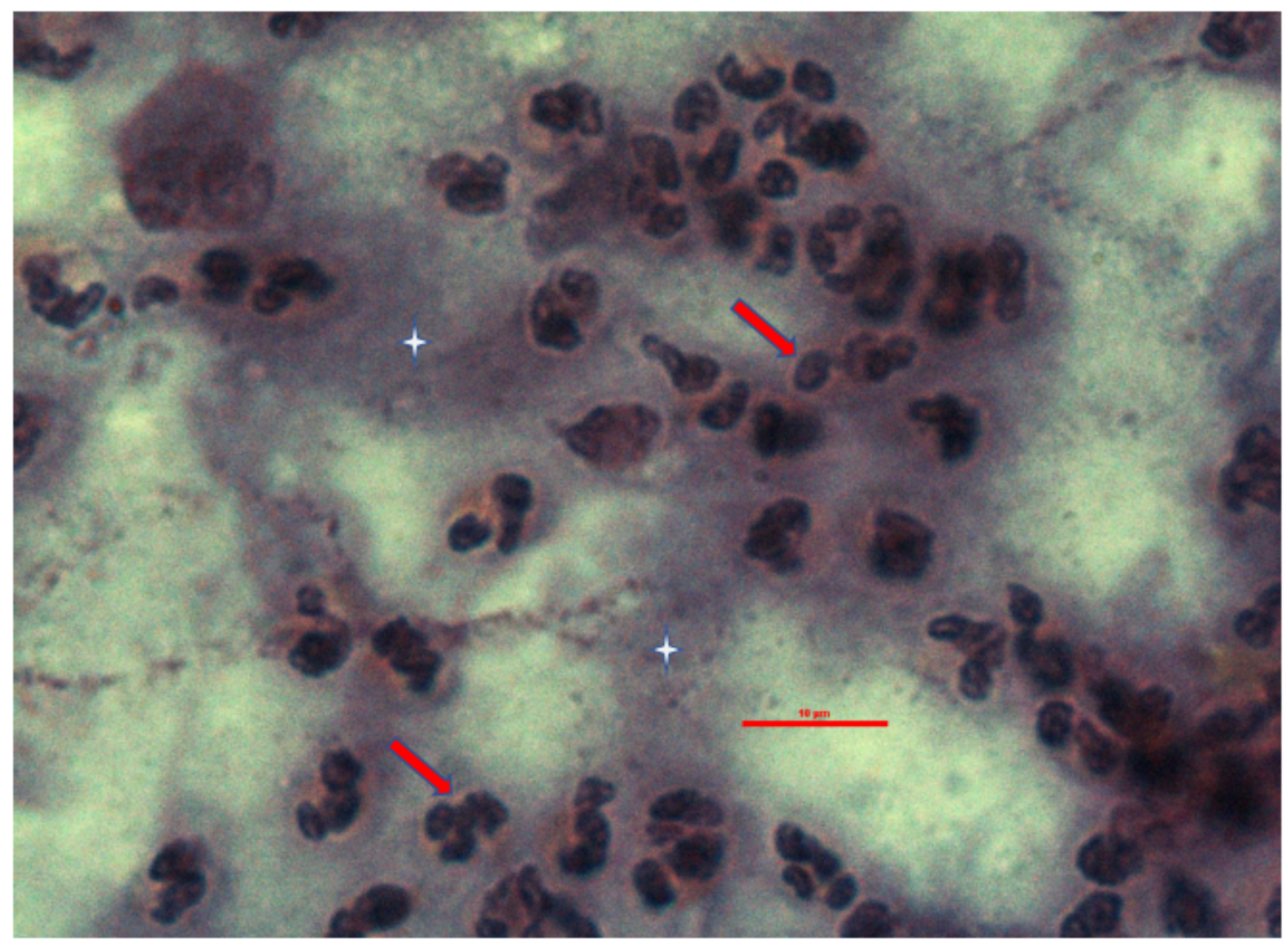

\section{Figure 1}

Numerous neutrophils (arrow) in heavily blue coloured (cross) smear because of the mucus. Observation by optical microscope. Magnification at $1000 \mathrm{X}$ oil immersion. Col. MGG. 


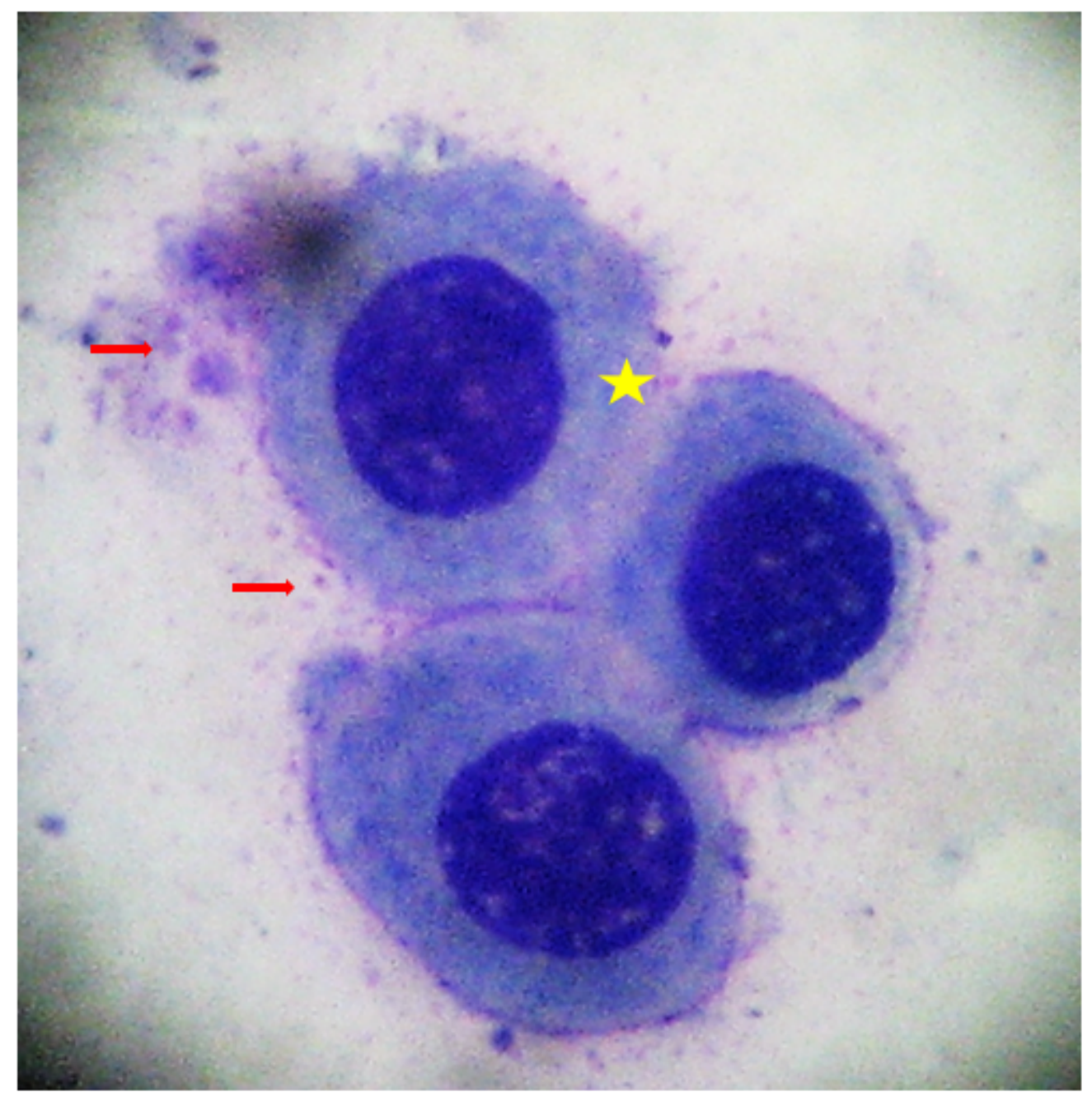

\section{Figure 2}

Lymphocytes (star) and dust precipitates (arrow). Observation by optical microscope. Magnification at $1000 \mathrm{X}$ oil immersion. Col. MGG (part.) 


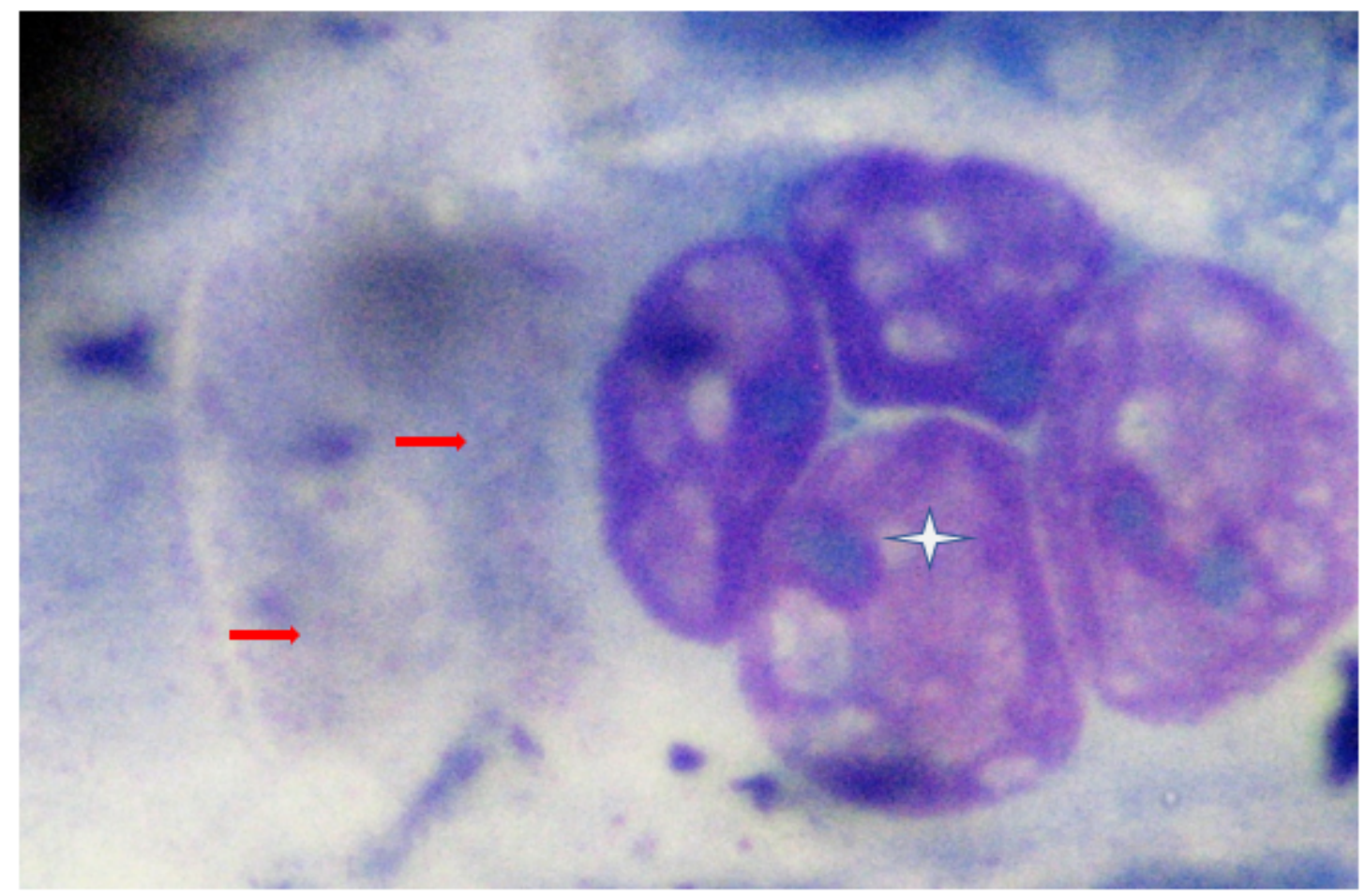

Figure 3

Polynucleate cell (cross) and dust precipitates (arrow). Observation by optical microscope. Magnification at $1000 \mathrm{X}$ oil immersion. Col. MGG (part.) 


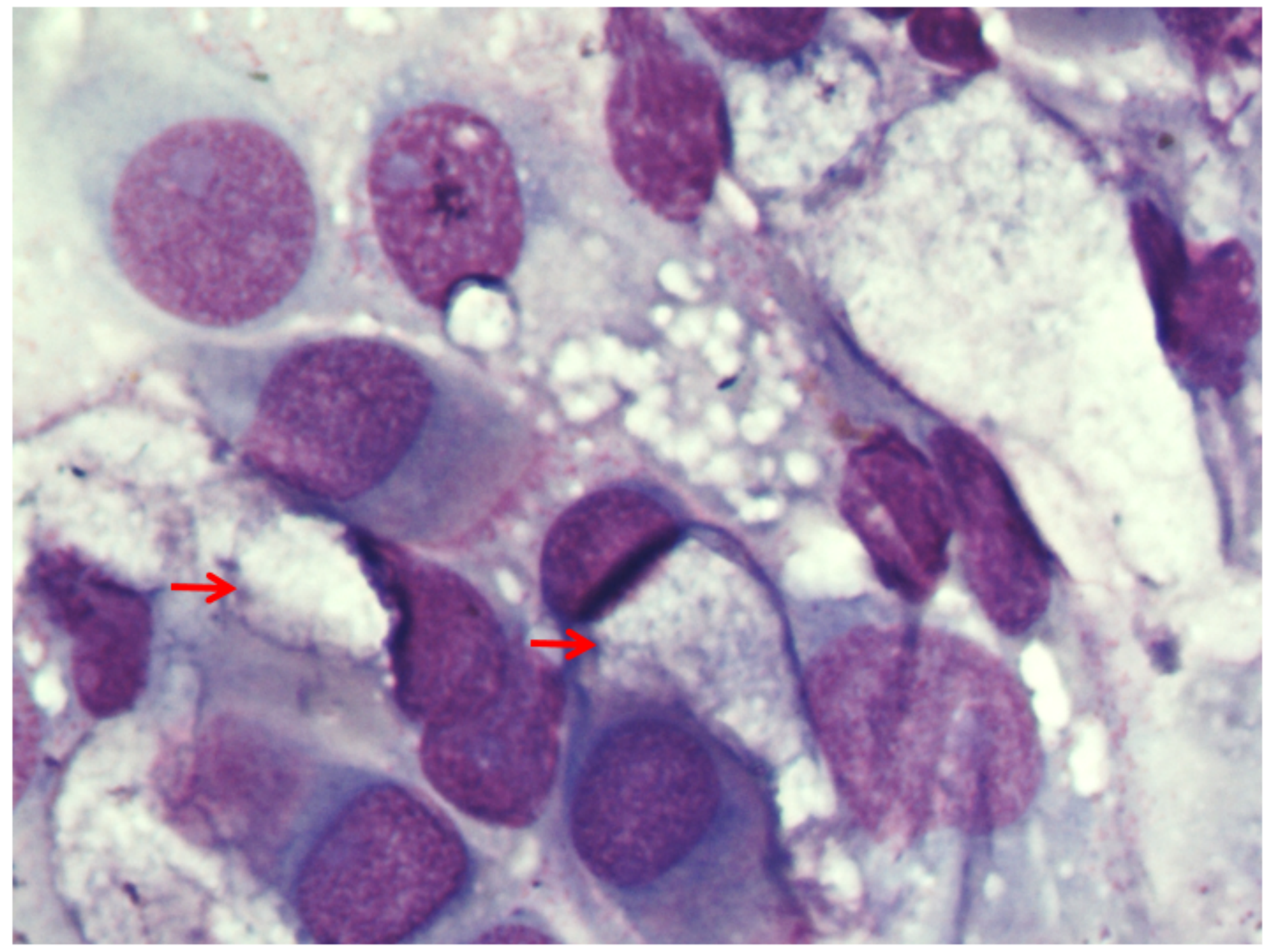

Figure 4

Muciparous metaplasia (arrow). Observation by optical microscope. Magnification at $1000 \mathrm{X}$ oil immersion. Col. MGG 